两个小租合扭成一个小組, 加强了業务組織領导, 对 工作量进行了科学的計算, 合理安排了組內每个同志 的工作，充分發揮了各人的积極性。原区系小組对新 罼業大学生沟有安排什么具体任务, 而躍进計划中都 分配了一定任务, 虽然按原計划有 14 人, 由于下放、 精简减少了 4 人, 但每个人要發掩出两个人的作用。

5. 把区系的調查研究与鍳定工作打成一片, 在农 業季节主要作区系研究，在冬季和初春集中力量搞分 离簽定和其他探索性試驗（如区采分析方法、土壤中 微生物活动产物等), 这样也就更充分地發揮了人力与 时閵的潜力。

6. 在保征質量和提高業务能力（包括学基础課及 查閱文献等) 方面, 桱过了具体討論分析一致認为, 由于加强了業务組織領导, 在正式試驗前多做几次准 备性試驗, 对新里業大学生給以基础訓䌀, 加之分工 明确, 計划各人心中有数, 合理支配时閏等条件, 完 全可以达到原訂五年計划中的要求。

\section{三、躍进的保証}

1. 党的領导、社会主义的优越性，这是保晸实現 躍进計划的先决条件。

2. 每个工作同志在繼續进行思想改造的基础上, 将进一步站稳工人阶級立場，一心一德，把心交給組 織、交給人民、交給柃会主义事業, 發揮集体作用, 不断鼓起革命干劲, 力爭上游, 在馬列主义思想指导 下，有組織的向科学进軍。

3. 老科学家的具体指导, 加强督促检查, 是保証 研究質量, 提高干部業务能力的关领建。

4. 行政各部門的大力支持, 各室、組間的互相合 作。

5. 学哲苏联是提高研究工作, 加速赶上国际先进 科学水平的捷径; 苏联在土堆微生物学方面, 正像其 他学科一样居于世界先列, 通过参加黑龙江流域規划

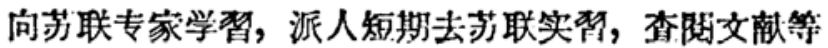
必将使工作大大推进。

6. 加强与所》有关部䅀的联系合作（如本所土裴

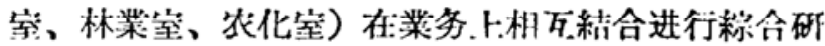
究; 争取和沈陽农学院、川东人器微生物研組在科 学研究上联系合作。

7. 躍进計划对今后几年內人力的發展作了詳細与 可靠的估計, 微生物室的研究生和留苏研究生都将陆 續参加工作和回国，每年也将不断增加新生力量。阁 志們都积極孚取有机会下放鉔炼，在有同志下放时， 全組同志将共同把任务担負起来。

\section{四、踟进計划实現的黄义}

躍进計划的实現将达到下列目标:

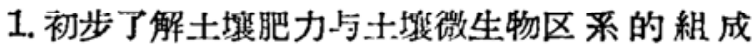

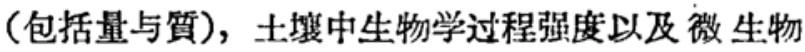
生命活动产物之間的关系。

2. 查明土壤微生物区采数量与类型的变化、生物 学过程强度等与土类的关系; 为研究土堆的生成登有 规律提供生物学資料。

3. 綃制成东北主要土类中常見細菌的圖諥，井收 集有关标准菌种, 为进一步深入研究土塯微生物区系 㓣造条件。

4. 建立起一套比較完整的土塯微生物区采的分析 方法, 緾成操作规程。

5 , 上述各項結果将为研究有机質的轉化和到殖颃 的积照創造条件。

总之, 在苦学苦干五年，实現躍进計划后，在十: 壤微生物区系的研究方法方面、土堆微生物分离器足定 方面及土坮中生物学过程强度的分析方法方面可以建 立起必要的基础，这就将为进一步深入研究土㙏微生 物区系，在第三个五年計划內，在某几項研究上赶上: 国际先进水平提供出可能和有利的条件。

\title{
打破陈規 建立新的工作組織形式
}

琚者按: 这里發表的是中国科学院实驗生物研究所的几张大字报。在科学研究工作方 面, 以問題为中心, 通过任务安排力量, 这是正确的, 而且是最有效的一种方式，在科学为 生产服务方面說起来是如此，在学科本身的發展方面說起来，当然，亦复如是。实瞼生物研 究所的这些张大字报，不只是說明了应該这样做，这样做得通，而且也証实了必須先标思想 大躍进，然后才可能有科学的大躍进。 


\section{我所的轉折点一一解开裹脚布}

我們初步确定:

1. 打破現有小組的界限。

2. 建立以問題为中心的工作小組。

3. 暫以胚胎生理、溜肿、再生与蚕的研究为中心 問題。

4. 所有工作人員都按照中心問題分配任务。 希些所有中初級工作人員提意見。

庄孝僡王高順謝世栋 '陈瑞銘 曾弥白匡达人朱潤吕家鸿 蔣天驞 张果李楚珩 罗 登

\section{革命的前奏}

我門坚决拥护全体高級人員提出的全所以四大問 題为中心, 重新調配力量的意見。我們認为这是我們 革命躍进的前奏。

我們欢呼反保守思想的巨大胜利。

我門表示决心, 千方百計地开动脑族积極参加争 諭。我們坚决保証做到服从組織分配, 必要时改行, 做突击手。

\section{李文裕 朱心良 王亚輝 王芸失 \\ 王应天 王佩瑜高慧刘筠 \\ 呂淑霞 张哲夫张玉硯 邓世章 \\ 刘世范沈立美 郑一守殿国㝘 \\ 墄爱光卢延龄莫慧英 陈汉源}

\section{拥护革命指施}

刚才李主任到我家里, 談起高級組决定在所內打 破原有各組的界限, 这是大躍进的革命措施。我完全
拥护。听到呂先生、陈先生要参加做煯肿工作更是兴 奋万状, 信心百倍。我願意做小学生向他 們二位 学 習, 向共同目标前进, 爭取在 5 年內做出成績, 十年 內赶上国际水平。

\section{毞 全}

我門势为: 姚、台、陈三位先生通力合作，围攻 㨨肿是上上策。理由如下:

一、姚先生組对肿瘤政究, 已有基础, 还利用紨 織化学方法做了一些工作。

二、呂先生用核酸的生物化学的研究經驗应用于 研究核酸瘤肿的生长关柔, 大有可为。

三、陈先生用組織培养方法来研究潜肿是解决溜 肿問題的重要方向。

四、三人合作，三种方法，互相配合，錦上添花， 大有可为, 大有希望。

五、溜肿問題是生物学上的重大問題，也是医学: 上最迫切需要解决的問题。

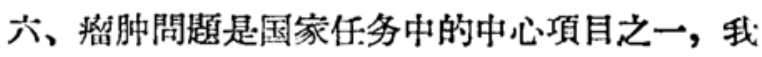
国急需建主癖肿研究基地。

$$
\begin{aligned}
& \text { 张玉硯 罗 登 李文裕 } \\
& \text { 朱心艮 王亚輝 }
\end{aligned}
$$

科学合作比如演戏，最忌爭扮“主角”。北京京剧 团, 馬、譚、装、张四塊头牌, 互相配合, 既演 主 㐿, 也演配角, 既可压軸, 也可开鑼。紧染合作, 晔 色不少。这种精神很值得学棔。

姚、呂、陈三塊“头牌”, “生”、“净”、“旦”皆 芼。热情的覌众，渴望能同台演出“取痛肿”这出好. “戏”。

\section{王亚輝}

\section{苏联經济的若干科学問題}

\section{—1958年3月7日在北京对經济学家和統計工作者所作的报告}

\section{B. C. 涅姆奇諾夫}

計划的社会主义国家需要自鸴地利用已經認識的 自然和社会的發展規律来为社会主义建設服务。因此 在社会主义国家中，对經济科学工作者或在計划和統 計部門工作的实际工作者的要求，也大大地提高了。

在社会主义国家中，經济学家、計划工作者和統 計工作者是特种的社会工程师，他們不仅应当在質上
揭露經济和社会过程的本質, 而且应当对这些过程进 行量的估計。如果不用数字和尺度来衡量經济和社会 过程就不可能自覚地利用已經認識的社会發展規律, 只有同时运用質的經济分析方法和量的統計方法与数 学方法, 才能揭示社会规律的作用力。

社会主义社会的經济結构和社会結构的复杂性要 